INTERNATIONAL JOURNAL OF RESEARCHES IN BIOSCIENCES, AGRICULTURE AND TECHNOLOGY

(c) VISHWASHANTI MULTIPURPOSE SOCIETY (Global Peace Multipurpose Society) R. No. MH-659/13(N)

www.ijrbat.in

\title{
ATRAZINE MEDIATED HEPATHOLOGICAL DISABILITIES IN FRESH WATER FISH AMEIURUS MELAS
}

\author{
Kusarkar S.P1. Khabade S.A2 and Nikalje S.B, 3 \\ 1, 2 Department of Zoology P.D.V.P Mahavidyalaya, Tasgaon, District- Sangli (Maharashtra). \\ ${ }^{3}$ Department of Zoology, Smt. Kasturbai Walchand College, Sangli (Maharashtra), India. \\ Corresponding author: kusarkarshailaja1995@gmail.com
}

\begin{abstract}
:
In present investigation the fish Ameiurus melas was exposed to the acute(96hours) toxicity of Atrazine. The LC50 was found to be $120 \mu \mathrm{g} / \mathrm{L}$. The control group was run simultaneously. After $96 \mathrm{hrs}$ the fish were dissected and the liver tissue was taken out and processed for routine $\mathrm{HE}$ technique. It was found that Atrazine is hepatotoxic to Ameiurus melas.. In the liver of control fish, no pathological alteration and no vacuolation of the hepatic cell was recorded. The liver shows vacuolar degeneration of hepatocytes and disintegration of the sinusoids and ruptured veins are also reported.

Keywords: Ameiurus melas, Atrazine, Liver.
\end{abstract}

\section{INTRODUCTION:}

In the agricultural fields the use of herbicides to protect the crops from the attack of unwanted plants has been considered as an integral part of modern agricultural practice in the World. But indiscriminate use of this is dangerous to aquatic ecosystems as well as fish farm which are close to agricultural field. They ultimately reach to aquatic bodies and cause harmful effect on non target aquatic animals such as fishes. Herbicides are most commonly used pesticides in agriculture. Thus it causes adverse impact on aquatic biota. A high concentration of herbicides reduces the survival, growth and reproduction rate of fishes and produces many adverse effects (Rahman et.al2002).

Atrazine is a widely used herbicide in many countries for controlling grassy weeds in agricultural crop. Prolonged use of Atrazine and its persistence involves the risk of its retention in crop and soil. This compound also passes from surface to ground water (Mundiamet.al, 2011). Atrazine (2chloro-4-ethylamino-6-isopropylamino-1,3,5-

triazine) is a herbicide first approved for use in US in 1958, where it is used primarily in the field of corn, sorghum and sugarcane(Solomon et.al; 1996). Atrazine inhibit electron transport in photosynthesis
II which result in disruption of photosynthesis and in turn leads to death from starvation in broad leaf plant (Gidding et.a12004).

Several recent laboratory studies have shown that environmentally realistic concentration of Atrazine have significant toxic effect on fish. For example - low concentration of Atrazine $(1 \mu \mathrm{g} / \mathrm{l})$ altered olfactory mediated endocrine function in male Atlantic Salmon (Moore and Lower, 2001). At $100 \mu \mathrm{g} / 1$ Atrazine altered the $\mathrm{Na}, \mathrm{K}$ and ATP are activity in common carp held in fresh water, indicating osmoregulatory disturbances (Hanke et.al, 1983). In recent years considerable histopathological studies have been conducted on fish exposed to sub lethal concentration of different pesticides and herbicides (Alazemi B.M., Lewis J.W. and Andrews.E.B., 1996). As a result the tissue changes are the functional responses of organisms which provide information on the nature of toxicant. Fishes are the most useful bio-indicator of environmental quality because of their close contact with water (De flora et.al, 1993). Thus toxicity studies are essential for determining sensitivity of animals to toxicants and also useful for evaluating the degree of damage to target organs and the consequent physiological, biochemical and 
behavioural disorders. To supplement risk assessment studies of this herbicide, it is important to obtain information on their toxicity and effect on some local species of fish. Therefore, the objectives of the present investigation are to characterize and compare the histological and structural alterations induced by Atrazine on liver of Ameiurus melas.

\section{MATERIAL METHODS:}

Present investigation has been carried out to study the effect of Atrazine on liver of the fresh water fish Ameiurus melas. Healthy specimen of Ameiurus melas of equal size group $(14 \pm 3 \mathrm{~cm})$ and average weight (14 to $16 \mathrm{gm}$ ) are collected from Yerala river. The fishes were kept in glass aquarium containing 80 lit water in laboratory at about water temperature $25 \pm 3^{\circ} \mathrm{c}$. Fishes are acclimatized for 30 days in the glass aquarium in laboratory condition before experiment. During the period of acclimatization fishes were fed daily with commercial fish food. The Atrazine herbicide purchased from local market and a pilot experiment was run to find out LC50 value of Atrazine by probit analysis of Finney(1964) and LC50 for 96 hrs was found to be $120 \mu \mathrm{g} / \mathrm{lit}$.

In this experiment, the specimen was kept in two experimental groups. Control group was without treatment of Atrazine and experimental group was treated with Atrazine. For Histological studies tissue was collected from both the group at four different time intervals (24hrs,48hrs,72hrs and 96hrs). The HE technique was used for histological study of liver of the fish Ameiurus melas. The liver tissue was excised and cut into the small pieces of suitable size for histology. Tissue was fixed into Bouin's fixative. The tissue was fixed in fixative for 18 hours and processed for paraffin sectioning as per routine micro technique. The $0.5 \mu$ thickness wax sections were further processed and stained with Hematoxylene and eosin. The tissue slides were evaluated using light microscope.

\section{RESULT \& DISCUSSION :}

Many researchers have evaluated the effects of Atrazine on fish (reviewed by Gidding et.al.2005; Huber 1993; Solomon et.al.1996). The present study deals with the hepatological alteration due to the atrazine herbicide on Ameiurus melas. In present investigation it has ben found that atrazine is hepatotoxic to Ameiurus melas. In the liver of control fish, no pathological alteration and no vacuolations of the hepatocytes and hepatic cell was recorded. Vacuolar degeneration of hepatocytes and disintegration of the sinusoids were distinctly observed in fish liver treated with Atrazine herbicide. Observed damage to liver tissue occurred as a result of exposure of fish to Atrazine. In present study ruptured veins are also reported. Increased vacuolization on hepatocytes is a sign of degenerative process (Pacheo and Santos 2002). Similar results were observed by Papoola Omoniyi Michael (2018) in fish Clarias gariepinus

\section{CONCLUSION.}

The histopathological analysis indicate that the liver is more sensitive to Atrazine induced damage. After 96 hrs of exposure major histopathological changes were observed. Vacuoles are ruptured due to Atrazine treatment. Vacuolar degeneration of sinusoids were the major alteration observed in fish liver. Vacuoles in the cytoplasm of hepatocytes contain lipid and glycogen which is related to the normal metabolic function of the liver.

\section{REFERANCE :}

De Flora S, Vigano SL, 1993 D 'Agostini F, Camoirano A, Baagnosco M, Bennicelli C et al., Multiple genotoxicityBiomarks in fish exposed in situto polluted river water mutation research;319:167-177.

Giddings JM, Anderson TA, Hall LW, Kendall RJ, Richards RP, Solomon KR, et al. 2005.A Probabilistic Aquatic Ecological Risk Assessment of Atrazine to North American Surface Waters. Pensacola, FL:SETAC Press.

Hanks, R.J. 1983. Yeild and water use relationships: An ovaeview.p. 393-411. In H.M. Taylor et.al. (ed) Limitations to efficient 
water use in crop production.ASA,CSSA,SSSA, Madsion,WI.

Huber W.1993. Ecotoxicological relevance of atrazine in aquatic system. Environ Toxicolchem $12 ; 1865-1881$.

Mundiam MKR, Pathak SP, Gopal K, Murthy RC, 2011. Studies on urban drinking water quality in tropical zone. Environmental monitoring Access, DOI 10.1007/s10661013.

Pacheco M, Santos MA .2002, Biotransformation, genotoxic and histopathological effect of environmental contaminants in European eel (Anguilla Anguilla).Ecotoxicology and Environmental Safety. ; 53:331-347

Popoola Omoniyi Michael 2016. Toxicity effect of atrazine on histology, haematology and biochemical indices of Clarias geriepinus, International Journal of Fisheries and Aquatic Studies, 6 (3): 87-92.
Rahman MZ, Hossain ZM, Ellah MFR, Ahmed GU.2002, Effect of diazinon 60ES on Anobustestudineus., Channapunstatus AND Barbadesgomonous. NAGA. The CLARM quarterly ; 25:8-11.

Solomon K.R, carr J.A, Preez L.H. 2008, Effect of atrazine on fish, amphibians, and aquatic reptiles : a critical review in toxicology;38(9):721-772.

Moore, A and Lower, N., 2001. The impact of two pesticides on olfactory mediated endocrine function in mature male Atlantic Salmon (Salmo salar L.) parr. Comparative Biochemistry and physiology,B129,269-276.

Mundiam MKR, Pathak SP, Gopal K, Murthy RC. 2011. Studied on urban drinking water quantity in a tropical zone . Environmental Monitoring Access. DOI 10.1007/s 10661013.

Plate-I: Showing the architecture of control and treated liver of Ameiurus melas

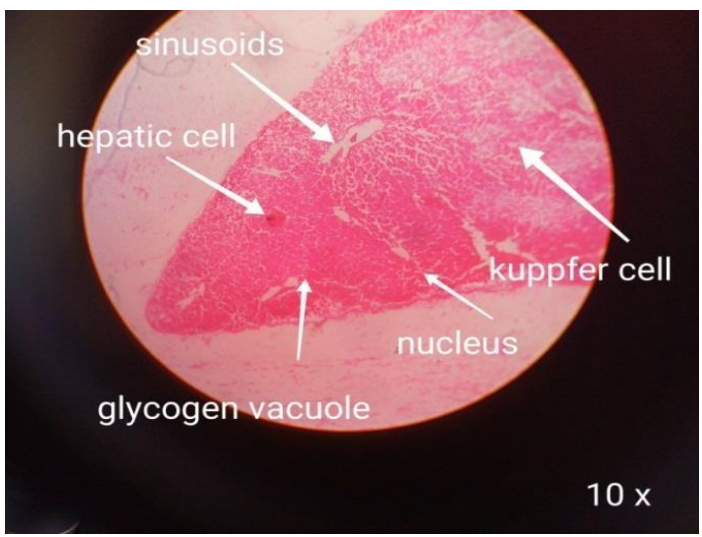

Fig A- T.S of liver of Ameiurus melas showing control .

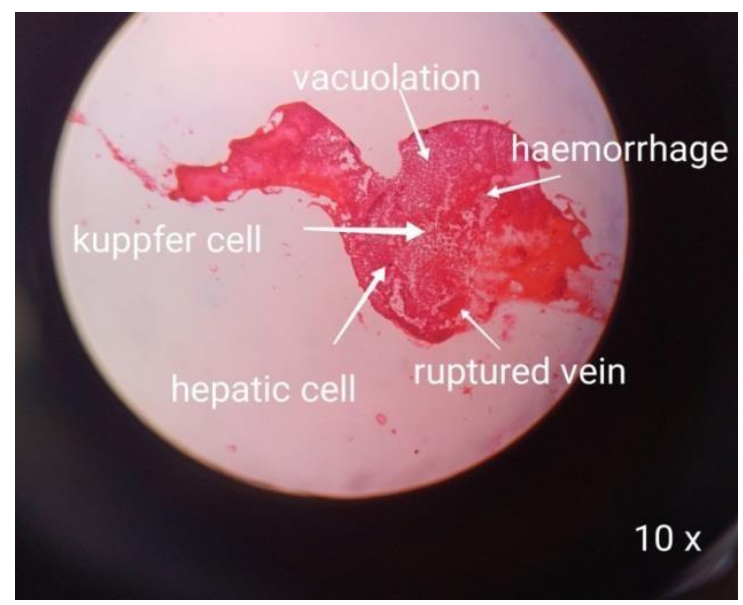

Fig B- T.S of Atrazine treated (96 hrs) liver of Ameiurus melas showing histopathological changes 